\title{
Glycine-Insensitive NMDA-Sensitive Receptor Expressed in Xenopus Oocytes by Guinea Pig Cerebellar mRNA
}

\author{
Masayuki Sekiguchi, Koichi Okamoto, and Yutaka Sakai \\ Department of Pharmacology, National Defense Medical College, 3-2 Namiki, Tokorozawa, Saitama 359, Japan
}

\begin{abstract}
The electrophysiological and pharmacological properties of $\mathrm{N}$-methyl-D-aspartate (NMDA)-sensitive receptors expressed in Xenopus oocytes by injection of total poly(A)+RNAs (mRNAs) from the cerebellum and cerebrum of guinea pigs were compared. The inward current induced by NMDA under voltage-clamp in cerebellar mRNA-injected oocytes was depressed in a voltage-dependent fashion by $\mathrm{Mg}^{2+}$ to show a negative slope conductance and selectively antagonized by D-2-amino-5-phosphonovalerate (D-APV) and phencyclidine (PCP). Glycine (0.01-10 $\mu \mathrm{M})$ did not potentiate NMDA-induced currents in cerebellar mRNA-injected oocytes, while it potentiated NMDA-induced currents in cerebral mRNA-injected oocytes in a dose-dependent fashion. 6-Cyano-7-nitroquinoxaline-2,3-dione and 7-chlorokynurenate suppressed the NMDA response but significantly less potently in cerebellar mRNA-injected oocytes than in cerebral mRNA-injected oocytes. These results suggest that the NMDA-sensitive receptor expressed in Xenopus oocytes by guinea pig cerebellar mRNA resembles the cerebral NMDA receptor in its high sensitivities to $\mathrm{Mg}^{2+}, \mathrm{PCP}$, and D-APV, but it is distinct from the cerebral NMDA receptor in responsiveness to glycine.
\end{abstract}

Excitatory amino acid receptors in the mammalian cerebrum are classified into either 3 subtypes, $N$-methyl-D-aspartate (NMDA), quisqualate (QA), and kainate (KA) receptors, or 2 subclasses, NMDA and non-NMDA types (Foster and Fagg, 1984). Among them, the NMDA receptor has attracted the most attention because of its possible role in high-order brain functions such as the long-term potentiation (LTP) in the hippocampus (Bliss and Gardner-Medwin, 1973; Bliss and Lømo, 1973; Collingridge and Bliss, 1987; Mayer and Westbrook, 1987).

The cerebral NMDA receptor may be characterized by the following 4 electrophysiological and pharmacological properties: (1) its response to NMDA is depressed in a voltage-dependent fashion by $\mathrm{Mg}^{2+}$ to show a negative slope conductance (Mayer et al., 1984; Nowak et al., 1984); (2) glycine potently enhances the NMDA response (Johnson and Ascher, 1987; Kleckner and Dingledine, 1988); (3) D-2-amino-5-phosphonovalerate (D-APV) is the specific antagonist of the NMDA receptor (Watkins and Evans, 1981); and (4) phencyclidine (PCP)

\footnotetext{
Received May 22, 1989; revised Dec. 21, 1989; accepted Jan. 4, 1990

We wish to thank Dr. Toshitaka Nabeshima, the Department of Pharmacology, Faculty of Pharmaceutical Sciences, Meijo University, Nagoya, Japan, for his kind offer of a sample of phencyclidine, and also Professor Yasuo Takahashi, The Brain Research Institute, Niigata University, Niigata, Japan, for his advice on the extraction of mRNA.

Correspondence should be addressed to Koichi Okamoto at the above address. Copyright (C) 1990 Society for Neuroscience $0270-6474 / 90 / 072148-08 \$ 03.00 / 0$
}

is the relatively specific open channel-blocker of the calcium channel linked to the NMDA receptor (Anis et al., 1983; Barker et al., 1983; Berry et al., 1984; Coan and Collingridge, 1985; Duchen et al., 1985; Harrison and Simmonds, 1985; Honey et al., 1985; Mayer and Westbrook, 1985; Thomson and Lodge, 1985).

However, there appears to be a regional heterogeneity in NMDA-sensitive receptors in the brain, as suggested by the following findings: (1) Rat cerebellar and spinal cord neurons are almost insensitive to quinolinate (QNL), an endogenous NMDA receptor agonist, while the cerebral cortical, hippocampal, and neostriatal neurons are sensitive to QNL (Perkins and Stone, 1983). (2) The potentiation by glycine of ${ }^{3} \mathrm{H}$-glutamate binding to NMDA receptors was significantly greater in the thalamus and cerebral cortex than in the cerebellum, septum, and striatum of the rat (Monaghan et al., 1988). (3) ${ }^{3} \mathrm{H}-1-(1-(2-$ thienyl)cyclohexyl)-piperidine ( $\left.{ }^{3} \mathrm{H}-\mathrm{TCP}\right)$, a potent radioligand for a PCP-binding site on the NMDA receptor, shows a low affinity for NMDA receptors in the rat cerebellum (Lawrence et al., 1988). Although these findings may be to suggest an NMDA receptor heterogeneity and might reflect multifunctional roles of NMDA receptors in the brain, direct electrophysiological or pharmacological evidence for the heterogeneity has not yet been presented.

For the purpose of electrophysiologically exploring a regional difference in the NMDA receptor between the cerebrum and ccrcbcllum, the propertics of the NMDA-sensitive receptor expressed in Xenopus oocytes by guinea pig cerebellar mRNA were compared with those of the cerebral NMDA receptor similarly expressed.

\section{Materials and Methods}

Messenger RNA was extracted from the cerebellum or cerebrum of adult male guinea pigs (350-500 gm, Hartley strain) according to the method of Chirgwin et al. (1979), but the cerebellar or cerebral microsomal fraction was used as a starting material as described previously (Sekiguchi et al., 1989). Briefly, the microsomal fraction was homogenized in $6 \mathrm{M}$ guanidinium thiocyanate solution containing $5 \mathrm{~mm} \mathrm{Na-citrate}$ and $0.5 \% \mathrm{Na}$-lauroylsarcosine, and ultracentrifuged at $160,000 \times g$ for $17 \mathrm{hr}$ at $20^{\circ} \mathrm{C}$ on a $5.7 \mathrm{M} \mathrm{CsCl}$ cushion containing $0.1 \mathrm{M} \mathrm{Na}$-EDTA (pH 7.4). Precipitated total RNA was dissolved in $10 \mathrm{~mm}$ Tris- $\mathrm{HCl}$ buffer ( $\mathrm{pH} 7.4$ ) containing $5 \mathrm{~mm}$ EDTA and $0.1 \% \mathrm{Na}_{3}$-dodecylsulfate, and washed thoroughly with a phenol/chloroform/iso-amylalcohol mixture $(25: 24: 1$ by vol), then with a chloroform/iso-amylalcohol mixture (24:1 by vol). After the total RNA was precipitated by ethanol, mRNA was separated by oligo-dT cellulose column chromatography and precipitated by ethanol. The mRNA precipitate was dissolved in sterile water to be $1-2 \mathrm{mg} \mathrm{mRNA} / \mathrm{ml}$, and about $50 \mathrm{ng}$ of mRNA (about 30 nl) was injected into each Xenopus laevis oocyte (at stage V or VI, a diameter of $>1.0 \mathrm{~mm}$, and with clear animal and vegetal hemispheres) basically by the method of Gundersen et al. (1984a).

The oocytes injected with mRNA were incubated at $19^{\circ} \mathrm{C}$ for $2-4 \mathrm{~d}$ 
in modified Barth's medium consisting of (in mM) $\mathrm{NaCl}, 88 ; \mathrm{KCl}, 1$; $\mathrm{NaHCO}_{3}, 2.4 ; \mathrm{HEPES}(\mathrm{pH} 7.6), 15 ; \mathrm{Ca}\left(\mathrm{NO}_{3}\right)_{2}, 0.3 ; \mathrm{CaCl}_{2}, 0.41 ; \mathrm{MgSO}_{4}$, 0.82 , supplemented with streptomycin- $\mathrm{SO}_{4}, 100 \mathrm{mg} / \mathrm{liter}$, and penicillin-K, 10,000 U/liter, and then treated with collagenase $(1 \mathrm{mg} / \mathrm{ml})$ for $2-3 \mathrm{hr}$ at room temperature $\left(22-24^{\circ} \mathrm{C}\right)$ to defolliculate. (In some experiments, the oocytes were first treated with collagenase, then mRNA was injected to examine whether the collagenase treatment affects receptors' expression, but no difference was noted.) The defolliculated oocyte was placed (one oocyte at a time) in a recording well $(0.5 \mathrm{ml}$ capacity) and superfused at $5 \mathrm{ml} / \mathrm{min}$ with frog Ringer's solution consisting of $125 \mathrm{~mm} \mathrm{NaCl}, 2 \mathrm{mM} \mathrm{KCl}, 1.8 \mathrm{mM} \mathrm{CaCl}_{2}$, and $5 \mathrm{~mm}$ HEPES (pH 7.4).

In all experiments in which the effect of antagonists or glycine was to be compared between cerebral mRNA-injected oocytes and cerebellar mRNA-injected oocytes, mRNAs were extracted respectively from 10 cerebra and 10 cerebella of 10 guinea pigs and injected into oocytes from a single mother frog.

Each test substance was dissolved in frog Ringcr's solution at various concentrations and applied to oocytes by constant flow superfusion (5 $\mathrm{ml} / \mathrm{min}$ ). Since the NMDA responses of oocytes injected with cerebral mRNA, but not with cerebellar mRNA, were too small, the frog Ringer's solution containing $10 \mu \mathrm{M}$ glycine was superfused for cerebral mRNAinjected oocytes, except for experiments to determine the effect of the amino acid itself. All solutions used were prepared with double-distilled autoclaved water $(12 \mathrm{M} \Omega / \mathrm{cm}$ or more $)$ to minimize contaminations with $\mathrm{Mg}^{2+}$, etc.

Responses of oocytes to test substances were recorded at room temperature by a voltage-clamp technique (clamped at $-60 \mathrm{mV}$ unless otherwise stated) using 2 glass microelectrodes both filled with $3 \mathrm{M} \mathrm{KCl}$ at 5-10 M $\Omega$, one for current recording and the other for current injection through the voltage-clamp unit (CEZ-1100, Nihon Kohden, Tokyo). Current signals from oocytes were recorded by the recorder responding up to $1 \mathrm{kHz}$ (WS-641G, Nihon Kohden) and also stored on magnetic tape (FE-35S, Sony, Tokyo). Intracellular recordings from oocytes were also performed using a single glass microelectrode (filled with $3 \mathrm{M} \mathrm{KCl}$, 5-10 M $\Omega$ ), but the results were employed only for a supplementary purpose.

NMDA, QA, DL-2-amino-5-phosphonovaleric acid (DL-APV), D-APV, and $\gamma$-D-glutamylglycine (DGG) were purchased from Funakoshi Chemical Co. (Tokyo, Japan). L-Glutamic acid diethylester (GDEE) was obtained from Sigma Chemical Co. (St. Louis, MO), and 6-cyano-7nitroquinoxaline-2,3-dione (CNQX) and 7-chlorokynurenic acid (7-ClKYN) were from Tocris Neuramin (Essex, England). Phencyclidine was a gift from Dr. Toshitaka Nabeshima of the Department of Pharmacology, Faculty of Pharmaceutical Sciences, Meijo University (Nagoya, Japan). The other chemicals used, including L-glutamic acid, L-aspartic acid, and collagenase, were obtained from Wako Pure Chemical Industries (Tokyo).

\section{Results}

\section{Membrane potentials and responsiveness of $m R N A$-injected and noninjected oocytes}

The mean resting membrane potential (RMP) was $-50.2 \pm 1.7$ $( \pm$ SEM) $\mathrm{mV}$ for 50 randomly selected oocytes injected with cerebellar mRNA and defolliculated, $\quad 51.8 \pm 1.8 \mathrm{mV}$ for 20 oocytes injected with cerebral mRNA and defolliculated, and $-51.0 \pm 2.9 \mathrm{mV}$ for 11 randomly selected defolliculated oocytes to which no mRNA was injected.

In oocytes that did not receive mRNA, 0.1-2 mM NMDA or L-aspartate (Asp) applied by superfusion sometimes induced small hyperpolarizations (1-3 mV), but no depolarizing response was induced by NMDA, Asp, QA, or glutamate (Glu), even when these agonists were applied at concentrations as high as $1 \mathrm{~mm}$ (data not shown).

\section{Inward currents induced by excitatory amino acids}

The oocytes injected with cerebellar mRNA became responsive to all excitatory amino acids tested. Either intracellularly recorded depolarizing responses or smooth/oscillating inward current responses under voltage-clamp to QA and Glu were ob- served in all 105 cerebellar mRNA-injected oocytes (mRNAs from 8 separate batches), and those to NMDA and Asp were observed in 102 of 105 oocytes; the remaining 3 oocytes responded neither to NMDA nor to Asp, but only to QA and Glu.

QA and Glu exhibited both smooth and oscillating inward currents or depolarizations; oscillating responses were observed in 32 out of 128 QA applications and 18 out of 74 Glu applications. The smooth and oscillating inward currents induced by QA $(50 \mu \mathrm{M})$ are illustrated in Figure $1 C$ (left) and $D$, respectively. The record in Figure $1 D$ was obtained from the same cell as in Figure $1 C$. Though not shown here, the shape of Glu-induced oscillating inward currents was similar to the oscillating QA response shown in Figure $1 D$. On the other hand, NMDA and Asp primarily showed smooth responses (e.g., see Fig. $1 A, a$ ); oscillating responses were observed in only 2 of 156 NMDA applications and in 3 of 68 Asp applications. As seen in Figure $1, A-C$, smooth inward current responses to excitatory amino acids were elicited after latencies as short as 5-20 sec. Although no large desensitization to NMDA, Asp, Glu, or QA was observed in all oocytes tested, a slight $(<15 \%)$ initial decline in current amplitude was usually noted in repetitive applications of NMDA similar to those described by Verdoorn et al. (1989). Therefore, only the NMDA responses stabilized after this initial decline were employed.

Figure $1 A, a$ and $b$ illustrates the dose dependence of the smooth inward current responses to 1-1000 $\mu \mathrm{M}$ NMDA of a cerebellar mRNA-injected oocyte in normal frog Ringer's solution containing neither $\mathrm{Mg}^{2+}$ nor glycine $(a)$ and a cerebral mRNA-injected oocyte in the frog Ringer's solution containing no $\mathrm{Mg}^{2+}$ and $10 \mu \mathrm{M}$ glycine $(b)$. As shown in Figure $1 A, a$ and $b$, the oocytes injected with cerebral and cerebellar mRNAs showed approximately equivalent responses in the NMDA concentration range of $1-1000 \mu \mathrm{M}$, when $10 \mu \mathrm{M}$ glycine was added to the medium superfusing cerebral mRNA-injected oocytes.

The mean response to $100 \mu \mathrm{M}$ NMDA of cerebral mRNAinjected oocytes in the frog Ringer's solution with no added glycine was $2.3 \pm 0.7 \mathrm{nA}(n=5)$; see Figure $5 A, b$, for example. On the basis of this finding, we decided to make routine additions of $10 \mu \mathrm{M}$ glycine to the frog Ringer's solution superfusing cerebral, but not cerebellar, mRNA-injected oocytes.

The $\mathrm{ED}_{50}$ value for NMDA in either cerebral mRNA-injected oocytes or cerebellar mRNA-injected oocytes was found to change from about $30 \mu \mathrm{M}$ to about $200 \mu \mathrm{M}$ depending primarily upon a seasonal biological variation in the mother frog (see results for Figs. 6 and 7). However, despite this variation in $\mathrm{ED}_{50}$, the oocytes which were collected from one mother frog and injected with cerebral and cerebellar mRNAs showed approximately similar responses to NMDA, provided that glycine at $\sim 10 \mu \mathrm{M}$ was added to the superfusion medium for cerehral mRNA-injected oocytes.

\section{Effects of $D$-APV on NMDA-induced inward currents}

The effects of D-APV on NMDA-induced inward currents were comparatively studied in the oocytes injected with cerebellar and cerebral mRNAs. As shown in Figure $1 E, 0.1-10 \mu \mathrm{M}$ of D-APV suppressed the response to $100 \mu \mathrm{M}$ NMDA of cerebellar mRNA-injected oocytes (closed circles) slightly more effectively than that of cerebral mRNA-injected oocytes (open circles). There was a significant difference ( $p<0.05$, Student's $t$-test) between the 2 values (open and closed circles in Fig. $1 E$ ) at 10 $\mu \mathrm{M}$ D-APV. The concentration of D-APV to achieve $50 \%$ suppression $\left(\mathrm{IC}_{50}\right.$ ) of responses to $100 \mu \mathrm{M}$ NMDA was $14.3 \pm$ 


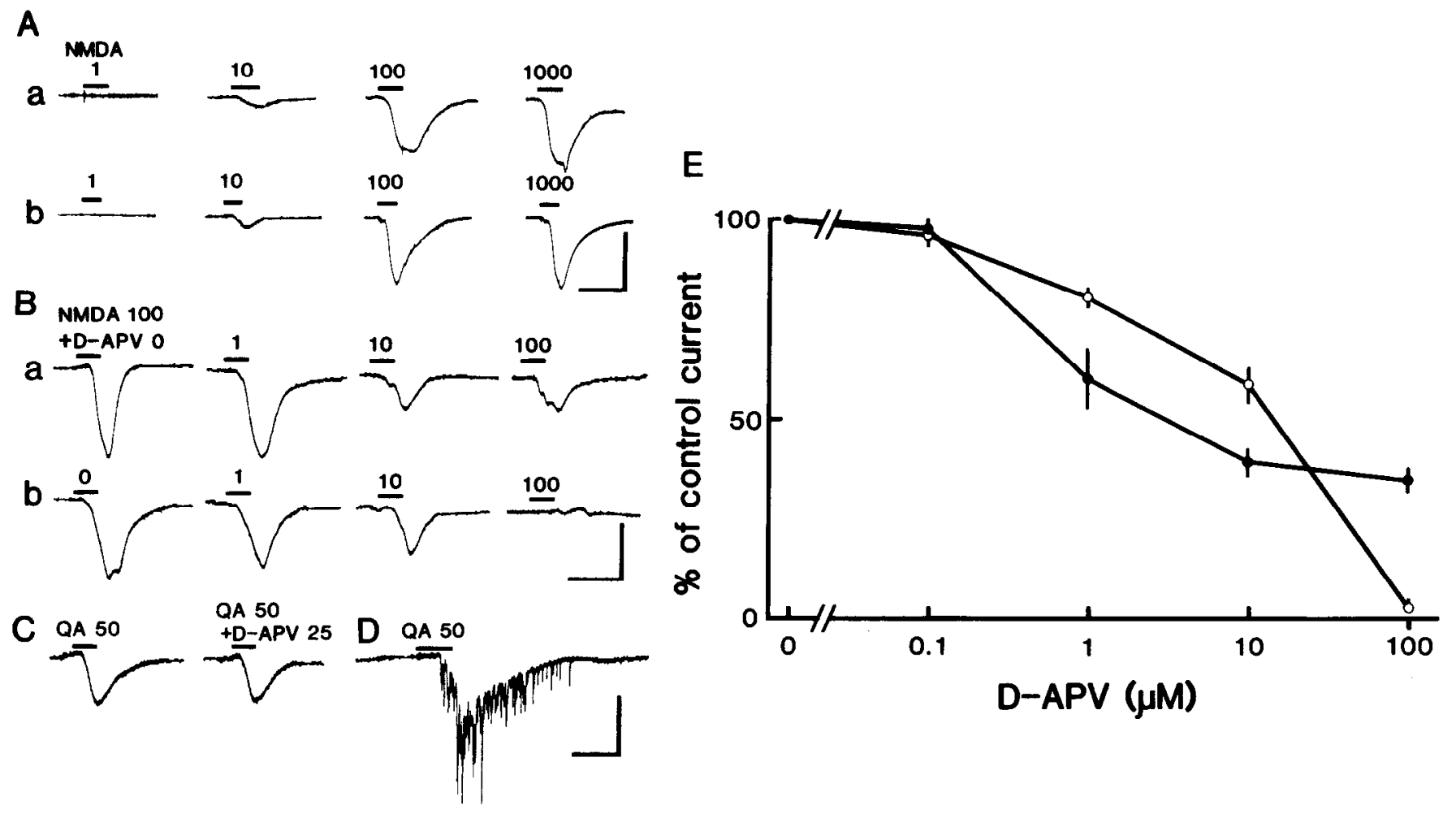

Figure 1. Responses to NMDA and QA of the oocytes injected with guinea pig cerebellar and cerebral mRNAs under voltage clamp, and the effects of D-APV. $A$, The inward currents induced by 1-1000 $\mu \mathrm{M}$ NMDA in the oocytes injected with cerebellar $(a)$ and cerebral $(b)$ mRNAs. NMDA was applied by superfusion for $30 \mathrm{sec}$ (bars), and the oocytes were clamped at $-60 \mathrm{mV}$ (also for $B-E$ ). $B$, The inhibitory effect of $1-100$ $\mu \mathrm{M}$ D-APV on responses to $100 \mu \mathrm{M}$ NMDA in the oocytes injected with cerebellar $(a)$ and cerebral $(b) \mathrm{mRN} \Lambda \mathrm{s}$. D-APV was applied together with NMDA for $30 \mathrm{sec}$ (also for $C$ and $E$ ). $C$, A smooth response to $50 \mu \mathrm{M}$ QA in a cerebellar mRNA-injected oocyte (left), and the lack of the inhibitory effect of $25 \mu \mathrm{M}$ D-APV thereon (right). $D$, An oscillating response to $50 \mu \mathrm{M}$ QA in the same cerebellar mRNA-injected oocyte as that of $C$. $E$, The dosc dependence of the blocking effects of D-APV on NMDA responses in the oucytes injected with cerebellar (closed circles) and cerebral (open circles) mRNAs. Mean values $( \pm$ SEM) from 3 oocytes are plotted. Ordinate: the percentage of the mean control current in the absence of D-APV $[35.9 \pm 4.9 \mathrm{nA}(n=3)$ and $33.6 \pm 2.4 \mathrm{nA}(n=3)$ for the oocytes injected with cerebellar and cerebral mRNAs, respectively]. Glycine $(10 \mu \mathrm{M})$ was added to the superfusion medium for cerebral mRNA-injected oocytes. Calibrations: vertical, $50 \mathrm{nA}$ for $A, C$, and $D$, and $25 \mathrm{nA}$ for $B$; horizontal, $1 \mathrm{~min}$ for all.

$2.8 \mu \mathrm{M}$ (mean $\pm \mathrm{SEM}, n=3)$ and $3.16 \pm 0.68 \mu \mathrm{M}(n=3)$ for the oocytes injected with cerebral and cerebellar mRNAs, respectively (values of mean $\mathrm{IC}_{50} \pm \mathrm{SEM}$ in the text were calculated by averaging the $\mathrm{IC}_{50}$ values individually estimated from dose-inhibition curves such as that in Fig. $1 E$ ). However, NMDA responses of cerebral mRNA-injected oocytes $(n=3)$ were consistently abolished by $100 \mu \mathrm{M}$ D-APV in such a manner as in Figure $1 E$ (open circle), whereas the currents induced by 100 $\mu \mathrm{M}$ NMDA in cerebellar mRNA-injected oocytes $(n=3)$ were not abolished, but rather were increased or unchanged, resulting in a mean suppression of about $35 \%$ at $100 \mu \mathrm{M}$ D-APV (Fig. $1 E$, closed circles).

In contrast to NMDA responses, QA-induced smooth inward currents in cerebellar mRNA-injected oocytes were much less sensitive to $25 \mu \mathrm{M} \mathrm{D}$-APV (Fig. $1 \mathrm{C}$ ), indicating that the inward currents induced by NMDA in cerebellar mRNA-injected oocytes were not mediated by $\mathrm{QA}$ receptors.

\section{$\mathrm{Mg}^{2+}$ - and voltage-dependence of NMDA-induced currents}

We wanted to determine whether NMDA-induced inward currents in cerebellar mRNA-injected oocytes depend on both $\mathrm{Mg}$ ions and the membrane potential in a similar manner as those in cerebral mRNA-injected oocytes. As mentioned above, since NMDA responses of cerebral mRNA-injected oocytes had to be recorded in the presence of glycine, the absolute $E D_{s 0}$ value for NMDA could not be estimated. Thus, the concentration of NMDA was tentatively fixed at $100 \mu \mathrm{M}$, and the mRNA-injected oocytes which showed comparable responses to $100 \mu \mathrm{M}$ NMDA (that is, the responses of cerebellar mRNA-injected oocytes in the absence of glycine were similar to those of cerebral mRNAinjected oocytes in the presence of $10 \mu \mathrm{M}$ glycine) were employed for this and subsequent comparative studies between the oocytes injected with cerebellar and cerebral mRNAs, unless otherwise stated.

As shown in Figure $2 A, a, b$, and $2 B$, NMDA responses of cerebellar mRNA-injected oocytes (closed circles) had a sensitivity to $\mathrm{Mg}^{2+}$ similar to that of cerebral mRNA-injected oocytes. The apparent $\mathrm{IC}_{50}$ value estimated at this concentration $(100 \mu \mathrm{M})$ of NMDA was $29.9 \pm 6.1 \mu \mathrm{M}(n=3)$ and $39.8 \pm 12.2$ $\mu \mathrm{M}(n=3)$ for cerebellar and cerebral mRNA-injected oocytes, respectively.

Responses to QA of cerebellar mRNA-injected oocytes were confirmed to be insensitive to $\mathrm{Mg}$ ions. As shown in Figure $2 B$, closed squares, the smooth inward current induced by $100 \mu \mathrm{M}$ $\mathrm{QA}$ in cerebellar mRNA-injected oocytes was little affected by $1-1000 \mu \mathrm{M} \mathrm{Mg}{ }^{2+}$, suggesting again that responses to NMDA and QA were mediated by distinct classes of receptor.

Figure $3 A$ shows the currents induced by $100 \mu \mathrm{M}$ NMDA in 

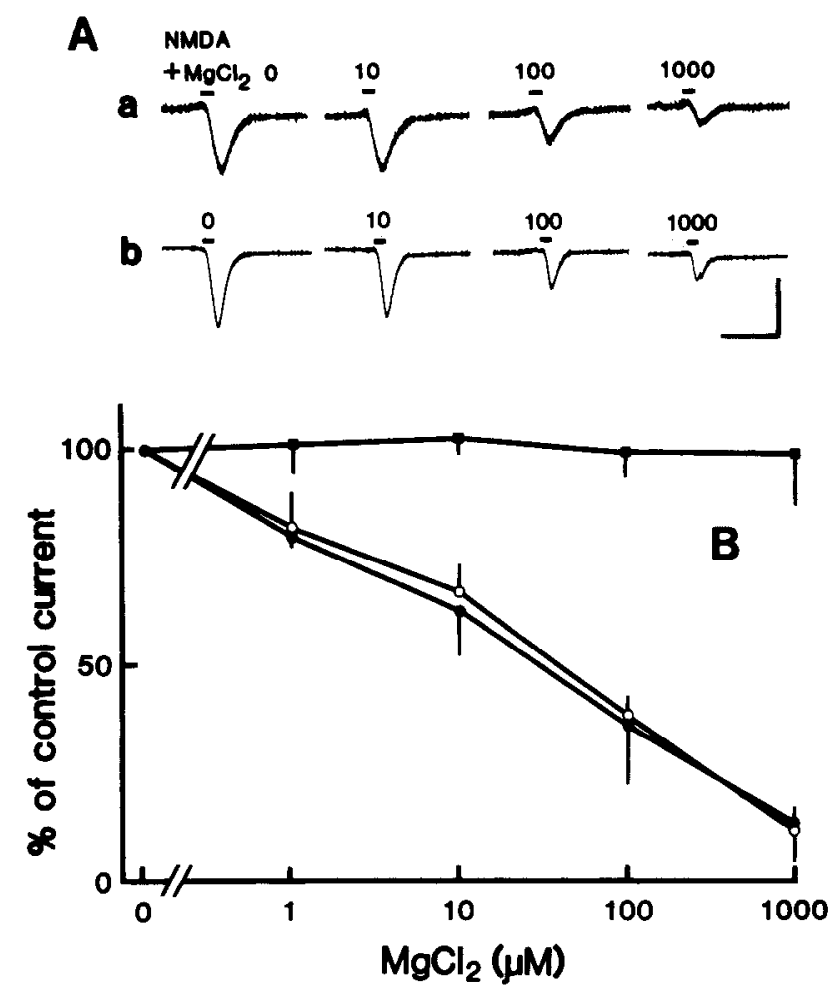

Figure 2. Dose dependence of the $\mathrm{Mg}^{2+}$ effect. $A$, The inward currents induced by $100 \mu \mathrm{M}$ NMDA applied for $15 \mathrm{sec}$ together with $0,10,100$, and $1000 \mu \mathrm{M} \mathrm{MgCl}$ to cerebellar $(a)$ and cerebral $(b)$ mRNA-injected oocytes, clamped at $-60 \mathrm{mV}$. Calibrations: vertical, $25 \mathrm{nA}$; horizontal, 1 min. $B$, Dose-response curves of the blocking action of $\mathrm{Mg}^{2+}$ on the inward current induced by $100 \mu \mathrm{M}$ NMDA in the oocytes injected with cerebellar (closed circles) and cerebral (open circles) mRNAs clamped at $-60 \mathrm{mV}$. Glycine $(10 \mu \mathrm{M})$ was present in the external medium for cerebral mRNA-injected oocytes. Mean values ( \pm SEM) from 3 cerebellar mRNA-injected oocytes and 3 cerebral mRNA-injected oocytes are plotted. Ordinate: percentage of the mean control current in the absence of $\mathrm{Mg}^{2+}[10.0 \pm 0.8 \mathrm{nA}(n=3)$ and $14.5 \pm 2.0 \mathrm{nA}(n=3)$ for cerebellar and cerebral mRNA-injected oocytes, respectively]. The lack of the $\mathrm{My}^{2}$ effect on the inward current induced by $100 \mu \mathrm{M}$ QA in cerebellar mRNA-injected oocytes $(n=3)$ is also shown (closed squares).

a cerebellar mRNA-injected oocyte at voltage-clamped membrane potentials of $-60,-30$, and $+10 \mathrm{mV}$ in the presence $(a)$ and absence $(b)$ of external $25 \mu \mathrm{M} \mathrm{Mg}{ }^{2+}$. Figure $3 B$ shows the mean $I-V$ relations obtained with $100 \mu \mathrm{M}$ NMDA in the absence (open circles) and presence of $25 \mu \mathrm{M} \mathrm{Mg}{ }^{21}$ (closed circles) in 34 cerebellar mRNA-injected oocytes and normalized at a membrane potential of $-40 \mathrm{mV}$. As shown in Figure $3 B$, closed circles, a negative slope conductance is seen in the presence of $25 \mu \mathrm{M} \mathrm{Mg}{ }^{2+}$ in a hyperpolarized membrane potential range.

\section{Effects of PCP on NMDA-induced inward currents}

Figure 4 shows the dose dependence of inhibition by PCP of the inward currents induced by $100 \mu \mathrm{M}$ NMDA in the oocytes injected with ccrebcllar mRNA and cerebral mRNA. PCP dosedependently suppressed NMDA responses in both cerebellar and cerebral mRNA-injected oocytes, but the inhibitory potency of PCP on $100 \mu \mathrm{M}$ NMDA was about 60 times stronger in cerebellar mRNA-injected oocytes; that is, apparent $\mathrm{IC}_{50}$ values were $0.53 \pm 0.37 \mathrm{nM}(n=3)$ and $33.0 \pm 4.0 \mathrm{nM}(n=3)$ for cerebellar and cerebral mRNA-injected oocytes, respectively.
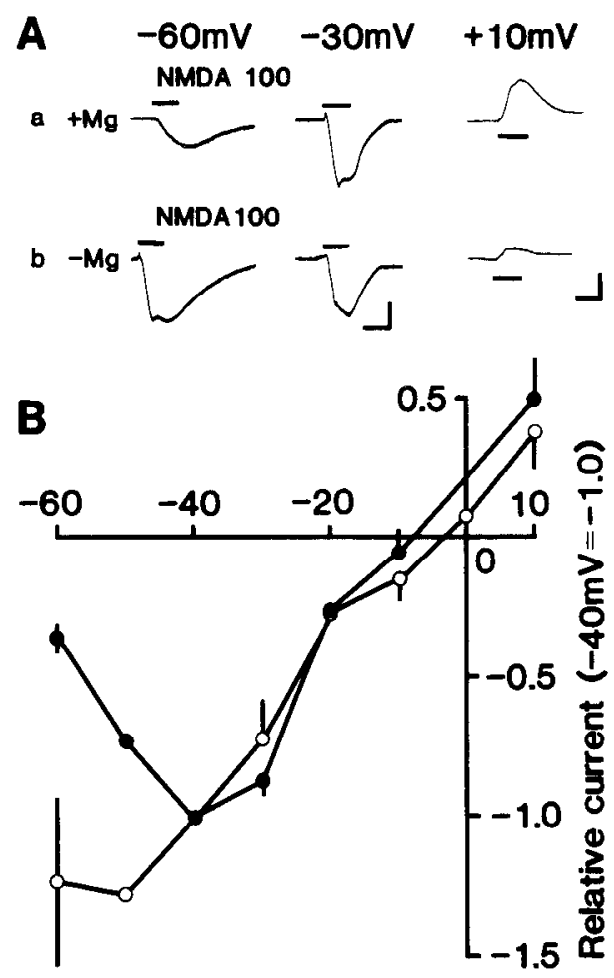

Figure 3. Voltage and $\mathrm{Mg}^{2+}$ dependence of the NMDA response. $A$, Inward currents induced by $100 \mu \mathrm{M}$ NMDA in a cerebellar mRNAinjected oocyte at clamped membrane potentials of $-60,-30$, and +10 $\mathrm{mV}(\mathrm{RMP}=-54 \mathrm{mV})$ in the presence $(a)$ and absence $(b)$ of $25 \mu \mathrm{M}$ external $\mathrm{Mg}^{2+}$. NMDA was applied by superfusion for $15 \mathrm{sec}$ (bars) at $100 \mu \mathrm{M}$. Calibrations: vertical, $12.5 \mathrm{nA}$ for the left 4 records and $25 \mathrm{nA}$ for the right 2 records; horizontal, 30 sec. $B$, The $I-V$ relations obtained hy a veraging 3-4 ohserved values in different cerebellar mRNA-injected oocytes in the presence (closed circles) and absence (open circles) of 25 $\mu \mathrm{M} \mathrm{Mg}{ }^{2+}$. Mean values ( \pm SEM) from 3-4 oocytes are plotted. Abscissa, membrane potential; ordinate, the current normalized at a membrane potential of $-40 \mathrm{mV}$; the mean currents at $-40 \mathrm{mV}$ were $30.7 \pm 1.3$ $\mathrm{nA}(n=4)$ and $35.0 \pm 1.2 \mathrm{nA}(n=4)$ in the presence and absence of $\mathrm{Mg}^{21}$, respectively.

\section{Effect of glycine on NMDA-induced inward currents}

Whether glycine can potentiate the responses of cerebellar mRNA-injected oocytes to NMDA was examined in comparison with cerebral mRNA-injected oocytes. This series of comparative studies first revealed a marked difference in the sensitivity of NMDA response to glycine between the oucytes injected with cerebellar and cerebral mRNAs. As shown in Figure $5 A, a$ and $B, 0.1-10 \mu \mathrm{M}$ glycine did not potentiate NMDAinduced inward currents in cerebellar mRNA-injected oocytes. The lack of potentiation by $0.1-10 \mu \mathrm{M}$ glycine was confirmed in a total of 9 cerebellar mRNA-injected oocytes. Moreover, glycine was also tested at higher concentrations such as 50 and $100 \mu \mathrm{M}$, but NMDA responses of cerebellar mRNA-injected oocytes were not potentiated at all (data not shown).

In contrast, NMDA responses in cerebral mRN $\Lambda$-injected oocytes were clearly and dose-dependently potentiated by glycine (Fig. 5A, $a$ and open circles in $B$ ), the concentration of glycine to achieve a 5 -fold increase being $0.63 \pm 0.20 \mu \mathrm{M}(n=$ 3). As mentioned earlier, NMDA also induced only a small $(\sim 1.5 \mathrm{nA})$ inward current in the absence of added glycine in this oocyte (Fig. $5 A, b$, leftmost trace), and such a small current 
A

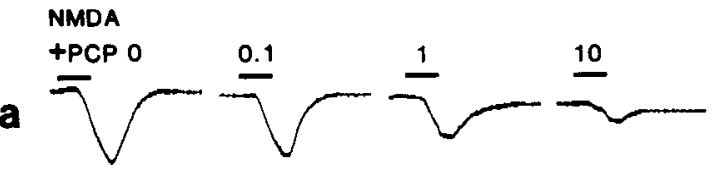

b $\frac{0}{2} \sqrt{\frac{1}{7}} \sqrt{\frac{100}{4}-\frac{1000}{1}}$

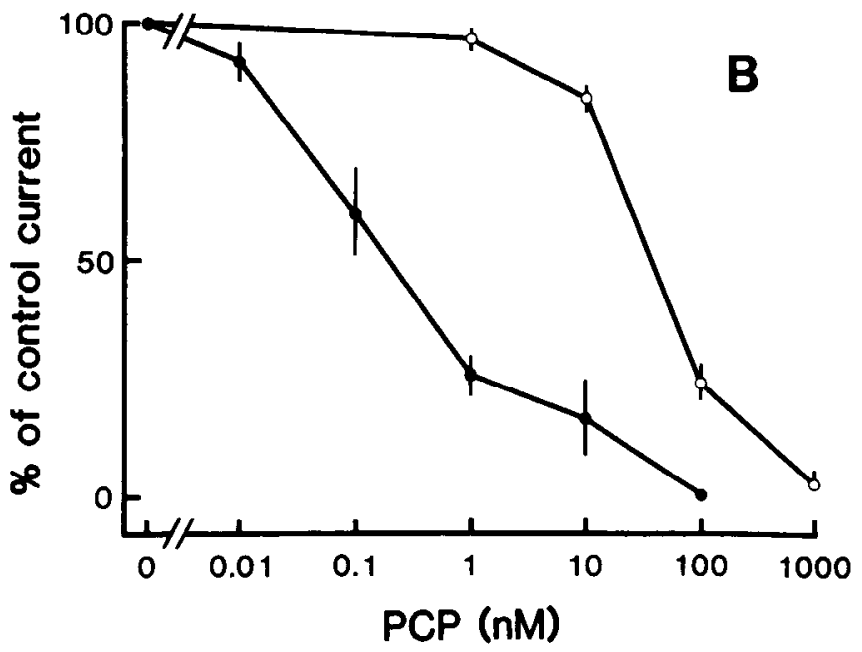

Figure 4. Effect of PCP on NMDA-induced inward currents. $A$, Inward current induced by $100 \mu \mathrm{M}$ NMDA applied for $30 \mathrm{sec}$ (bars) together with 0-1000 nM PCP to the oocytes injected with cerebellar $(a)$ and cerebral $(b)$ mRNAs, clamped at $-60 \mathrm{mV}$. Calibrations: vertical, 25 nA; horizontal, $1 \mathrm{~min} . B$, Dose-response curves of the inhibitory action of PCP on the inward currents induced by $100 \mu \mathrm{M}$ NMDA in the oocytes injected with cerebellar (closed circles) and cerebral (open circles) mRNAs, clamped at $-60 \mathrm{mV}$. All values plotted are the means $( \pm \mathrm{SEM})$ of 3 observations. Glycine $(10 \mu \mathrm{M})$ was present in the external medium for cerebral mRNA-injected oocytes. Ordinate: the percentage of the mean control current in the absence of PCP [26.7 $\pm 1.1 \mathrm{nA}(n=3)$ and 36.7 $\pm 0.8 \mathrm{nA}(n=3)$ for the oocytes injected with cerebellar and cerebral mRNAs, respectively].

was increased by nearly 10 -fold on average by $10 \mu \mathrm{M}$ glycine (Fig. $5 B$, open circle).

\section{Effects of 7-Cl-KYN and CNQX on NMDA-induced inward currents}

The glycine binding site on cerebral NMDA receptors is known to be blocked specifically by $7-\mathrm{Cl}-\mathrm{KYN}$ (Kemp et al., 1988; Donald et al., 1988). The effect of this antagonist was tested in order to confirm that the lack of the glycine effect reflects the characteristic property of the NMDA-sensitive receptors expressed in cerebellar mRNA-injected oocytes.

In this series of experiments (Figs. 6, 7), however, the test concentration of NMDA had to be raised to $300 \mu \mathrm{M}$ for cerebellar mRNA-injected oocytes and to $150 \mu \mathrm{M}$ (in the presence of $10 \mu \mathrm{M}$ glycine) for cerebral mRNA-injected oocytes in order to obtain equivalent responses. This was because the oocytes used for these experiments had a relatively low ability to translate mRNAs, a seasonal biological variation which is particularly prominent in the summer.
A
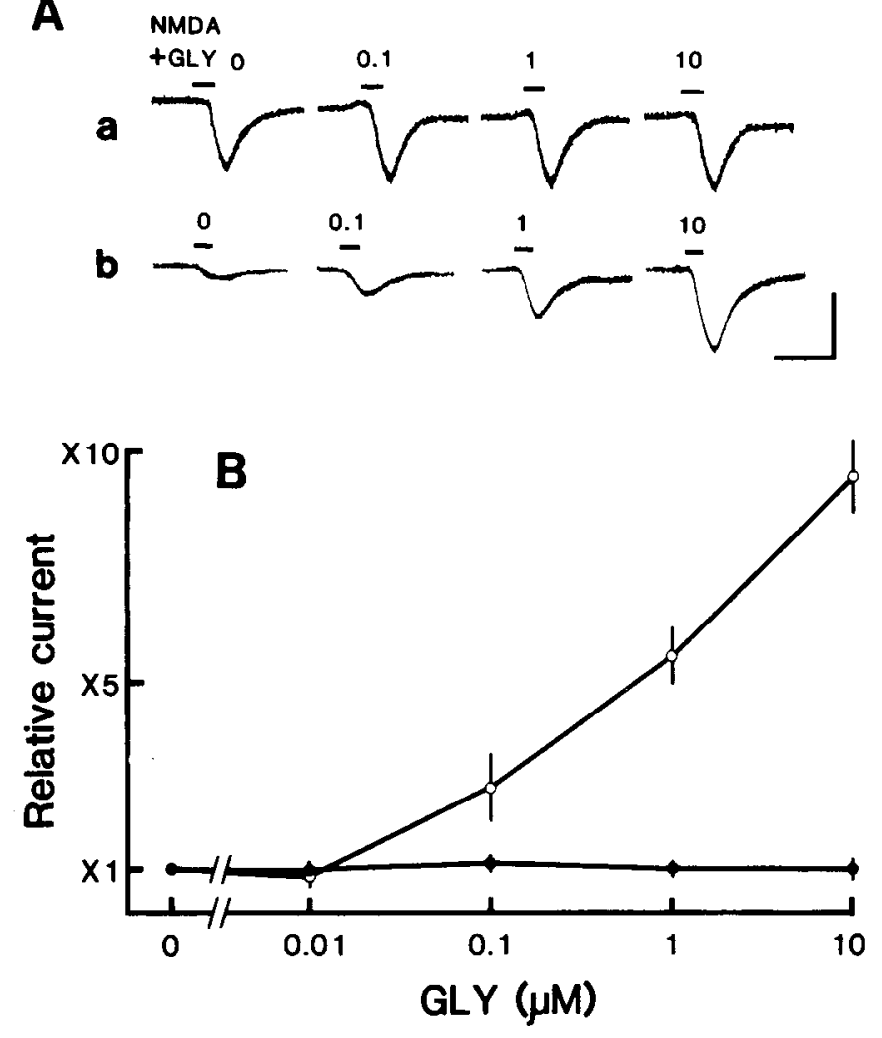

Figure 5. Effects of glycine on NMDA responses in the oocytes injected with cerebellar and cerebral mRNAs. $A$, Inward currents induced by $100 \mu \mathrm{M}$ NMDA applied for $30 \mathrm{sec}$ (bars) together with $0,0.1,1$, and $10 \mu \mathrm{M}$ glycine to the oocytes injected with cerebellar $(a)$ and cerebral (b) mRNAs, clamped at $-60 \mathrm{mV}$. Calibrations: vertical, $25 \mathrm{nA}$; horizontal, 1 min. $B$, Dosc-rcsponse curves of the potentiating action of glycine on responses to $100 \mu \mathrm{M}$ NMDA in the oocytes injected with cerebellar (closed circles) and cerebral (open circles) mRNAs, clamped at $-60 \mathrm{mV}$. Mean values $( \pm$ SEM) from 3 oocytes are plotted. Ordinate, the mean inward current expressed as the ratio to the mean control value in the absence of glycine $[48.3 \pm 10.9 \mathrm{nA}(n=3)$ and $2.2 \pm 0.8$ $\mathrm{nA}(n=3)$ for the oocytes injected with cerebellar and cerebral mRNAs, respectively].

As illustrated in Figure 6A, 7-Cl-KYN suppressed the inward current induced by NMDA in oocytes injected with cerebellar mRNA $(a)$ or cerebral mRNA $(b)$. Figure $6 B$ shows the doseresponse relations obtained from 3-4 mRNA-injected oocytes. Apparent $\mathrm{IC}_{50}$ values estimated from Figure $6 B$ were $225.7 \pm$ $30.9 \mu \mathrm{M}(n=4)$ and $11.0 \pm 2.8 \mu \mathrm{M}(n=3)$ for the oocytes injected with cerebellar (closed circles) and cerebral (open circles) mRNAs, respectively.

CNQX is also known to be an antagonist of the glycine binding site on cerebral NMDA receptors (Birch et al., 1988; Verdoorn et al, 1989). Figure $7 A$ exemplifies the dose-dependent suppressive effect of CNQX (1-150 or $300 \mu \mathrm{M})$ on the inward currents induced by NMDA in the oocytes injected with cerebellar (a) and ccrcbral mRNA (b). The dose-response curves obtained from 3 mRNA-injected oocytes are illustrated in Figure $7 B$. As shown in Figure $7 B$, CNQX only partially suppressed NMDA responses in cerebellar mRNA-injected oocytes (closed circles, $\mathrm{IC}_{50}>300 \mu \mathrm{M}, n=3$ ), although it completely inhibited those in cerebral mRNA-injected oocytes (open circles; $\mathrm{IC}_{50}=7.6 \pm$ $1.5 \mu \mathrm{M}, n=3$ ). 
A
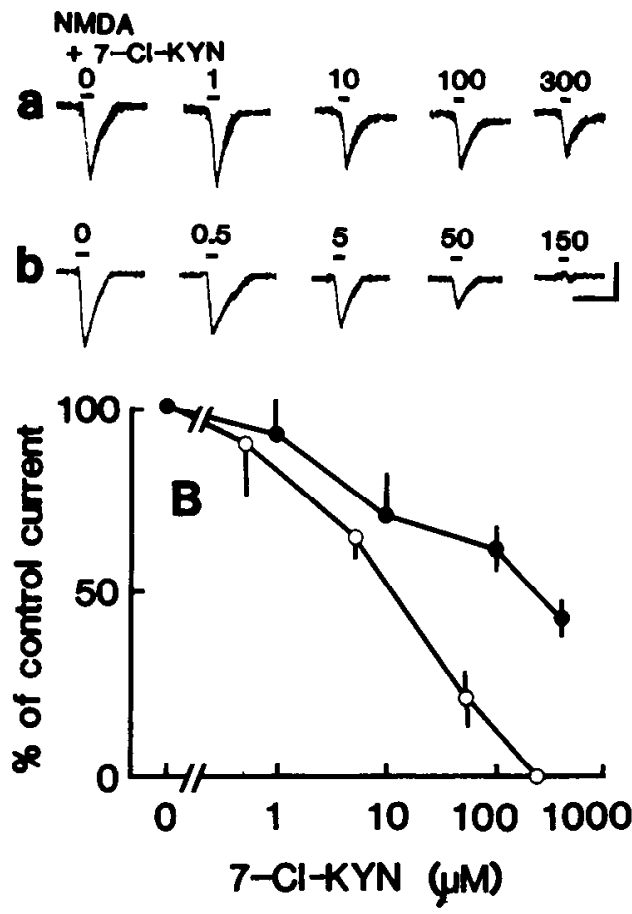

Figure 6. Antagonistic action of 7-Cl-KYN on NMDA responses in the oocytes injected with cerebellar and cerebral mRNAs. $A$, Effect of $1-300 \mu \mathrm{M} 7-\mathrm{Cl}-\mathrm{KYN}$ on the inward currents induced by $300 \mu \mathrm{M}$ NMDA in a cerebellar mRNA-injected oocyte $(a)$ and the effect of $1-150 \mu \mathrm{M}$ $7-\mathrm{Cl}-\mathrm{KYN}$ on the inward currents induced by $150 \mu \mathrm{M}$ NMDA in a cerebral mRNA-injected oocyte $(b)$, both clamped at $-60 \mathrm{mV}$. Calibrations: vertical, $25 \mathrm{nA}$; horizontal, $1 \mathrm{~min}$. $B$, Dose-response of the blocking action of 7-Cl-KYN (1-300 $\mu \mathrm{M}$ for cerebellar mRNA-injected oocytes and 1-150 $\mu \mathrm{M}$ for cerebral mRNA-injected oocytes) on the responses to $300 \mu \mathrm{M}$ NMDA of cerebellar mRNA-injected oocytes (closed circles) and to $150 \mu \mathrm{M}$ NMDA of cerebral mRNA-injected oncytes (open circles). Mean values ( \pm SEM) from 3-4 oocytes are plotted. Ordinate: the mean percentage of the control response in the absence of 7-Cl$\mathrm{KYN}[35.4 \pm 7.9 \mathrm{nA}(n-4)$ and $48.7 \pm 8.3 \mathrm{nA}(n=3)$ for the oocytes injected with cerebellar and cerebral mRNAs, respectively].

\section{Discussion}

The Xenopus laevis oocyte is now established as an effective expression system for excitatory amino acid receptors (Gundersen et al., 1984a, b; Houamed et al., 1984; Parker et al., 1985; Saito et al., 1987; Sugiyama et al., 1987; Verdoorn et al., 1987, 1989; Kleckner and Dingledine, 1988; Kushner et al., 1988; Sekiguchi et al., 1989).

NMDA receptors expressed in Xenopus oocytes by injection of rat cerebral mRNA have been proved to have essentially the same pharmacological and electrophysiological properties as neuronal NMDA receptors in the rat cerebrum (Verdoorn et al., 1987; Kushner et al., 1988). On the basis of this methodological support, we carried out the present study for the purpose of examining the regional difference of NMDA receptors by pharmacologically comparing NMDA responses in oocytes injected with mRNAs from the cerebellum and cerebrum of the guinea pig.

Growing evidence suggests possible differences between NMDA-sensitive receptors in the cerebellum and NMDA receptors in other brain regions. In addition to those mentioned in our introductory remarks, the following findings may also
A
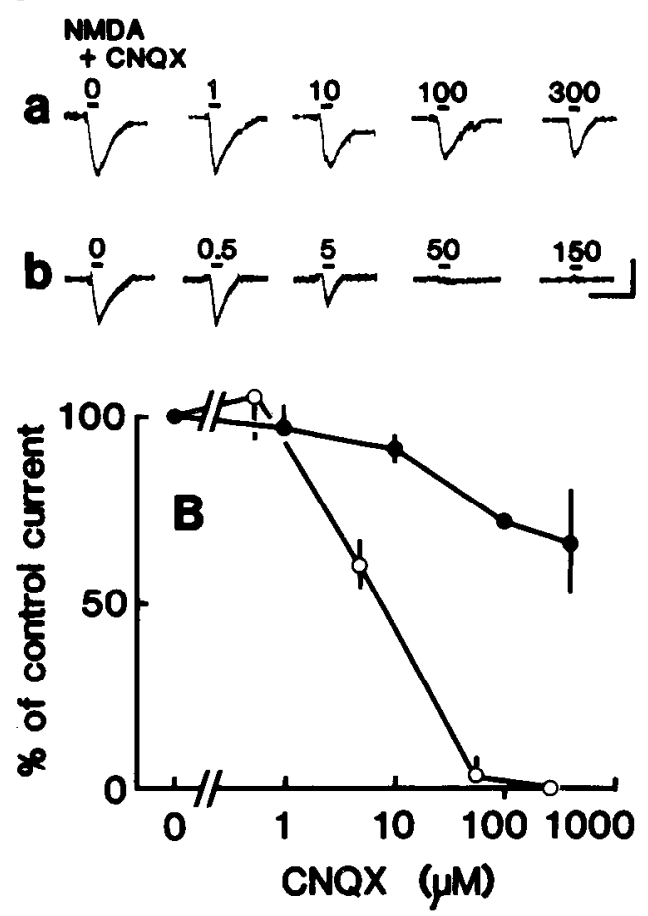

Figure 7. Antagonistic action of CNQX on NMDA responses in the oocytes injected with cerebellar and cerebral mRNAs. $A$, Effect of 1150 or $300 \mu \mathrm{M} \mathrm{CNQX}$ on the inward currents induced by $300 \mu \mathrm{M}$ NMDA in a cerebellar mRNA-injected oocyte $(a)$ and the effect of 1-150 $\mu \mathrm{M}$ CNQX on the inward currents induced by $150 \mu \mathrm{M}$ NMDA in a cerebral mRNA-injected oocyte $(b)$, both clamped at $-60 \mathrm{mV}$. Calibrations: vertical, $25 \mathrm{nA}$; horizontal, $1 \mathrm{~min}$. $B$, Dose-response of the blocking action of CNQX (1-300 $\mu \mathrm{m}$ for cerebellar mRNA-injected oocytes and 1-150 $\mu \mathrm{M}$ for cerebral mRNA-injected oocytes) on the responses to 300 $\mu \mathrm{M}$ NMDA of cerebellar mRNA-injected oocytes (closed circles) and to $150 \mu \mathrm{M}$ NMDA of cerebral mRNA-injected oocytes (open circles). Mean values $( \pm$ SEM) from 3-4 oocytes are plotted. Ordinate: the mean percentage of the control response in the absence of CNQX [38.0 \pm 3.0 $\mathrm{nA}(n=3)$ and $26.2 \pm 2.5 \mathrm{nA}(n=3)$ for the oocytes injected with cerebellar and cerebral mRNAs, respectively].

suggest the difference between the cerebellar NMDA-sensitive receptor and the cerebral NMDA receptor. (1) Rat cerebellar membranes show a low binding capacity to the specific ligand of cerebral NMDA receptors, ${ }^{3} \mathrm{H}-3-(( \pm) 2$-carboxypiperazine-4yl)propyl-1-phosphonic acid ( $\left.{ }^{3} \mathrm{H}-\mathrm{CCP}\right)$ (Cotman et al., 1987). (2) The number of PCP-binding sites is much smaller than that of NMDA receptors in the rat cerebellum (Jarvis et al., 1987; Kushner et al., 1988). (3) NMDA does not act as an agonist but is an antagonist of Asp-induced depolarizations and climbing fiber responses in the guinea pig cerebellar slices (Kimura et al., 1985). (4) DL-APV is not potent enough to abolish the NMDA or Asp response of Purkinje cells in vitro (Kimura et al., 1985; Sekiguchi et al., 1987).

On the other hand, as for the similarity to cerebral NMDA receptors, the $\mathrm{Mg}^{2+}$ and voltage dependence of the NMD $\Lambda$ response was reported for Purkinje cell dendrites in guinea pig cerebellar slices (Sekiguchi et al., 1987) and for intracerebellar nuclei neurons in cerebellar slices from immature rats (Gardette and Crepel, 1986), and the potentiating action of glycine was demonstrated in cultured granule cells from the rat cerebellum (Wroblewski et al., 1989). 
In the present study, NMDA responses in the oocytes injected with cerebellar and cerebral mRNAs were found to have the following properties: (1) NMDA-induced inward current in cerebellar mRNA-injected oocytes was not potentiated by glycine, whereas, under exactly the same experimental condition, the NMDA response of cerebral mRNA-injected oocytes was dosedependently potentiated by glycine (see Fig. 5). (2) NMDAinduced inward current in cerebellar mRNA-injected oocytes was voltage and $\mathrm{Mg}^{2+}$ dependent to show a negative slope conductance (see Fig. 3). (3) NMDA-induced inward current in cerebellar mRNA-injected oocytes was strongly blocked by PCP (Fig. 4).

The lack of the glycine effect on the NMDA response of oocytes injected with guinea pig cerebellar mRNA (Fig. 5) contrasts with the absolute requirement of glycine for appreciable NMDA responses of oocytes injected with cerebral mRNAs from the guinea pig (Fig. 5) and the rat (Kleckner and Dingledine, 1988). Before concluding that this lack of the glycine effect reflects the distinct nature of NMDA-sensitive receptors in the cerebellum, at least 2 possibilities must be considered: (1) NMDA activated not only NMDA-sensitive receptors but also glycine-insensitive non-NMDA receptors, and (2) glycine which leaked out of oocytes already potentiated the NMDA response in cerebellar mRNA-injected oocytes.

The first possibility, however, is unlikely because (1) the NMDA response of cerebellar mRNA-injected oocytes was highly sensitive to D-APV (Fig. 1), $\mathrm{Mg}^{2+}$ (Fig. 2), and PCP (Fig. 4), and was dependent upon membrane potential (Fig. 3), while smooth QA responses were not sensitive to D-APV (Fig. 1) or $\mathrm{Mg}^{2+}$ (Fig. 2); (2) $1 \mu \mathrm{M}$ PCP suppressed the depolarizations induced by $50 \mu \mathrm{M}$ NMDA to $13 \%$ of control and that by $50 \mu \mathrm{M}$ QA only to $71 \%$; (3) $10 \mu \mathrm{M}$ DGG depressed the NMDA response to $45 \%$ and the QA response to $74 \%$; and (4) $30 \mu \mathrm{M}$ GDEE suppressed the NMDA response to $98 \%$ and the QA response to $51 \%$. (Findings $2-4$ were from our separate experiments using intracellular recordings of cerebellar mRNA-injected oocytes.)

The second possibility also seems to be unlikely, although no direct evidence can be adduced at present. Our findings against this possibility may be that $7-\mathrm{Cl}-\mathrm{KYN}$, which is said to be a specific antagonist of the glycine binding site on cerebral NMDA receptors (Donald et al., 1988; Kemp et al., 1988), was significantly less effective on the NMDA response of cerebellar mRNAinjected oocyles than that of cerebral mRNA-injected oocyles (Fig. 6), and CNQX, which is reported to be the mixed competitive-noncompetitive antagonist of the glycine binding site (Birch et al., 1988; Verdoorn et al., 1989), was significantly less potent in cerebellar mRNA-injected oocytes than in cerebral mRNA-injected oocytes (Fig. 7). In addition, there is neither a compelling reason nor experimental support to postulate that an effective amount of glycine leaks out only from cerebellar mRNA-injected oocytes but not from cerebral mRNA-injected oocytes. The existence of a diffusion barrier against added glycine only in cerebellar mRNA-injected oocytes is also unlikely because both cerebellar mRNA-injected and cerebral mRNAinjected oocytes were similarly defolliculated by collagenase treatment.

On this basis, it may be at least suggested that the NMDAsensitive receptor expressed in oocytes by injection of guinea pig cerebellar mRNA is much less sensitive to glycine than the cerebral NMDA receptor similarly expressed in oocytes.

If the present findings were to suggest the absence of the glycine binding site on the cerebellar NMDA-sensitive receptor, one may expect a heterogeneity in NMDA receptors similar to that of the $\mathrm{GABA}_{\mathrm{A}}$ receptor (Levitan et al., 1988) and the glycine receptor (Akagi and Miledi, 1988). However, as demonstrated by Monaghan et al. (1988), glycine potentiates the agonist binding and reduces the antagonist binding to NMDA receptors in the rat brain. These authors further proposed the hypothesis that glycine causes a conversion of NMDA reccptors from an antagonist-preferring conformation (relatively unresponsive to Glu) to an agonist-preferring conformation (highly responsive to Glu). If this were the case, glycine-insensitive, NMDA-sensitive receptors in the cerebellum would be in a state similar to the agonist-preferring conformation regardless of the presence or absence of glycine.

According to Bristow et al. (1986) and Wroblewski et al. (1989), strychnine-insensitive glycine binding sites are present in the granule cell layer of the rat cerebellum. Whether these glycine binding sites are expressed in Xenopus oocytes, however, is unclear because a potentiating action of glycine was not observed in the present study.

As demonstrated in this study, the Xenopus oocyte system is suitable for exploration of receptor heterogeneity due to regional differences and will be useful for ontogenic and developmental investigations of receptors.

In conclusion, the NMDA-sensitive receptor expressed in Xenopus oocytes by injection of mRNA extracted from guinea pig cerebellum resembles the cerebral NMDA receptor in voltage-dependent sensitivity to $\mathrm{Mg}^{2+}$ and high susceptibilities to D-APV and PCP, but it is distinct from the cerebral NMDA receptor in responsiveness to glycine. The physiological role of this NMDA-sensitive receptor in synaptic transmission, including the long-term depression (Ito, 1984), in the cerebellum and its anatomical and functional relations to cerebellar nonNMDA receptors are matters of interest for further investigations.

\section{References}

Akagi H, Miledi R (1988) Heterogeneity of glycine receptors and their messenger RNAs in rat brain and spinal cord. Science 242:270-273.

Anis NA, Berry SC, Burton NR, Lodge D (1983) The dissociative anesthetics, ketamine and phencyclidine, selectively reduce excitation of central mammalian neurones by $\mathrm{N}$-methyl-aspartate. $\mathrm{Br} \mathrm{J}$ Pharmacol 79:565-575.

Barker JL, McBurney RN, Mathers DA (1983) Convulsant-induced depression of amino acid responses in cultured mouse spinal neurons studied under voltage clamp. Br J Pharmacol 80:619-629.

Berry SC, Dawkins SI , I odge D (1984) Comparison of $\sigma$ - and $\kappa$-opiate receptor ligands as excitatory amino acid antagonists. Br J Pharmacol 83:179-185.

Birch PJ, Grossman CJ, Hayes AG (1988) 6,7-Dinitro-quinoxaline2,3-dion and 6-nitro,7-cyano-quinoxaline-2,3-dion antagonize responses to NMDA via an action at the strychnine-insensitive glycine receptor. Br J Pharmacol 156:177-180.

Bliss TVP, Lømo T (1973) Long-lasting potentiation of synaptic transmission in the dentate area of the anaesthetized rabbit following stimulation of the perforant path. J Physiol (Lond) 232:331-356.

Bliss TVP, Gardner-Medwin AR (1973) Long-lasting potentiation of synaptic transmission in the dentate area of the unanaesthetized rabbit following stimulation of the perforant path. J Physiol (Lond) 232: $357-374$.

Bristow DR, Bowcry NG, Woodruff GN (1986) Light microscopic autoradiographic localisation of $\left[{ }^{3} \mathrm{H}\right]$ glycine and $\left[{ }^{3} \mathrm{H}\right]$ strychnine binding sites in rat brain. Eur J Pharmacol 126:303-307.

Chirgwin JM, Przybyla AE, MacDonald RJ, Rutter WJ (1979) Isolation of biologically active ribonucleic acid from sources enriched in ribonuclease. Biochemistry 18:5294-5299.

Coan EJ, Collingridge GL (1985) Ketamine and N-allynormetazocine selectively inhibit an N-methyl-D-aspartate-receptor-mediated com- 
ponent of synaptic transmission in rat hippocampal slices. J Physiol (Lond) 364:32P.

Collingridge GL, Bliss TVP (1987) NMDA receptors-their role in long-term potentiation. Trends Neurosci 10:288-293.

Cotman CW, Monaghan DT, Ottersen OP, Storm-Mathisen J (1987) Anatomical organization of excitatory amino acid receptors and their pathways. Trends Neurosci 10:273-280.

Donald AE, Tridgett R, Foster AC (1988) Characterization of the $\left[{ }^{3} \mathrm{H}\right]$ glycine binding to a modulatory site within the NMDA receptor complex from rat brain. Br J Pharmacol 95:892P.

Duchen MR, Burton NR, Biscoe TJ (1985) An intracellular study of the action of $\mathrm{N}$-methyl-DL-aspartate with ketamine in the mouse hippocampal slices. Brain Res 342:149-153.

Foster AC, Fagg GE (1984) Acidic amino acid binding sites in mammalian neuronal membranes: their characteristics and relationship to synaptic receptors. Brain Res 7:103-164.

Gardette R, Crepel F (1986) Chemoresponsiveness of intracerebellar nuclei neurones to $\mathrm{L}$-aspartate, $\mathrm{L}$-glutamate and related derivatives in rat cerebellar slices maintained in vitro. Neuroscience 18:93-103.

Gundersen CB, Miledi R, Parker I (1984a) Glutamate and kainate receptors induced by rat brain messenger RNA in Xenopus oocytes. Proc R Soc London [Biol] 221:127-143.

Gundersen CB, Miledi R, Parker I (1984b) Messenger RNA from human brain induces drug- and voltage-operated channels in Xenopus oocytes. Nature 308:421-424.

Harrison NL, Simmonds MA (1985) Quantitative studies on some antagonists of N-methyl-D-aspartate in slices of rat cerebral cortex. Br J Pharmacol 84:381-391.

Honey CR, Miljkovic Z, MacDonald JF (1985) Ketamine and phencyclidine cause a voltage-dependent block of responses to L-aspartic acid. Neurosci Lett 61:135-139.

Houamed KM, Bilbe G, Smart TG, Constanti A, Brown DA, Barnard EA, Richards BM (1984) Expression of functional GABA, glycine and glutamate receptors in Xenopus oocytes injected with rat brain mRNA. Nature 310:318-321.

Ito $M$ (1984). The cerebellum and neural control. New York: Raven, pp 58, 115-130.

Jarvis MF, Murphy DE, Williams M (1987) Quantitative autoradiographic localization of NMDA receptors in rat brain using [ $\left.{ }^{3} \mathrm{H}\right] \mathrm{CPP}$ : comparison with $\left[{ }^{3} \mathrm{H}\right] \mathrm{TCP}$ binding sites. Eur J Pharmacol 141:149152.

Johnson JW, Ascher P (1987) Glycine potentiates the NMDA response in cultured mouse brain neurones. Nature 325:529-531.

Kemp JA, Foster AC, Leeson PD, Priestley T, Tridgett R, Iversen LL, Woodruff GN (1988) 7-Chlorokynurenic acid is a selective antagonist at the glycine modulatory site of the N-methyl-D-aspartate receptor complex. Proc Natl Acad Sci USA 85:6547-6550.

Kimura H, Okamoto K, Sakai Y (1985) Pharmacological evidence for L-aspartate as the neurotransmitter of cerebellar climbing fibres in the guinea-pig. J Physiol (Lond) 365:103-119.

Kleckner NW, Dingledine R (1988) Requirement for glycine in activation of NMDA-receptors expressed in Xenopus oocytes. Science 241:835-837.

Kushner L, Lerma J, Zukin RS, Bennett MVL (1988) Cuexpression of N-methyl-D-aspartate and phencyclidine receptors in Xenopus oocytes injected with rat brain mRNA. Proc Natl Acad Sci USA 85: $3250-3254$.
Lawrence S-JY, Snell D, Johnson KM (1988) Linkage between phencyclidine (PCP) and N-methyl-D-aspartate (NMDA) receptors in the cerebellum. Brain Res 445:147-151.

Levitan ES, Schofield PR, Burt DR, Rhee LM, Wisden W, Kohler M, Fujita N, Rodriguez HF, Stephenson A, Darlison MG, Barnard EA, Seeburg PH (1988) Structural and functional basis for $\mathrm{GABA}_{\mathrm{A}}$ receptor heterogeneity. Nature 335:76-79.

Mayer ML, Westbrook GL (1985) Divalent cation permeability of N-methyl-D-aspartate channels. Soc Neurosci Abstr 11:785.

Mayer ML, Westbrook GL (1987) The physiology of excitatory amino acids in the vertebrate central nervous system. Prog Neurobiol 28: 197-276.

Mayer ML, Westbrook GL, Guthrie PB (1984) Voltage-dependent block by $\mathrm{Mg}^{2+}$ of NMDA responses in spinal cord neurones. Nature 309:261-263.

Monaghan DT, Olverman HJ, Nguyen L, Watkins JC, Cotman CW (1988) Two classes of N-methyl-D-aspartate recognition sites: differential distribution and differential regulation by glycine. Proc Natl Acad Sci USA 85:9836-9840.

Nowak L, Bregestovski P. Ascher P, Herbet A, Prochiantz A (1984) Magnesium gates glutamate-activated channels in mouse central neurones. Nature 307:462-465.

Parker I, Sumikawa K, Miledi R (1985) Messenger RNA from bovine retina induces kainate and glycine receptors in Xenopus oocytes. Proc R Soc London [Biol] 225:99-106.

Perkins MN, Stone TW (1983) Quinolinic acid: regional variations in neuronal sensitivity. Brain Res 259:172-176.

Saito M, Ohsako S, Deguchi T, Kawai N (1987) Glutamate receptors expressed in Xenopus oocyte by messenger RNA from invertebrate muscle. Mol Brain Res 3:83-87.

Sekiguchi M, Okamoto K, Sakai Y (1987) NMDA-receptors on Purkinje cell dendrites in guinea pig cerebellar slices. Brain Res 437:402406.

Sekiguchi M, Okamoto K, Sakai Y (1989) Low-concentration N-acetylaspartylglutamate suppresses the climbing fiber response of Purkinje cells in guinea pig cerebellar slices and the response to excitatory amino acids of Xenopus laevis oocytes injected with cerebellar mRNA. Brain Res 482:87-96.

Sugiyama H, Ito I, Hirono C (1987) A new type of glutamate receptor linked to inositol phospholipid metabolism. Naturc 325:531-533.

Thomson AM, Lodge D (1985) Selective blockade of an excitatory synapse in rat cerebral cortex by the sigma opiate cyclazocine: an intracellular study. Neurosci Lett 54:21-26.

Verdoorn TA, Kleckner NW, Dingledine R (1987) Rat brain N-methyl-D-aspartate receptors expressed in Xenopus oocytes. Science 238 : $1114-1116$.

Verdoorn TA, Kleckner NW, Dingledine R (1989) N-Methyl-D-aspartate/glycine and quisqualate/kainate receptors expressed in Xenopus oocytes: antagonist pharmacology. J Pharmacol Exp Ther 35: 360-368.

Watkins JC, Evans RH (1981) Excitatory amino acid transmitters. Annu Rev Pharmacol Toxicol 21:165-204.

Wroblewski JT, Fadda E, Mazzetta J, Lazarewicz JW, Costa E (1989) Glycine and $\mathrm{D}$-serine act as positive modulators of signal transduction at $\mathrm{N}$-methyl-D-aspartate sensitive glutamate receptors in cultured cerebellar granule cells. Neuropharmacology 28:447-452. 